\title{
Exploring Teachers' Beliefs and Practices in Early Childhood Classroom
}

\author{
Irena Y. Maureen \\ Department of Instructional Technology \\ University of Twente, the Netherlands \\ Program Studi Teknologi Pendidikan \\ Universitas Negeri Surabaya \\ i.y.maureen@utwente.nl
}

\author{
Mustaji, Mutiara Fhatrina, Sulistyowati \\ Program Studi Teknologi Pendidikan \\ Universitas Negeri Surabaya \\ Surabaya, Indonesia \\ fhatrina.mutiara@gmail.com
}

\begin{abstract}
The world of the future is and will be increasingly become digital and therefore, multicultural. The dynamic changes in how children learn and live challenged the early childhood teachers to adjust the curriculum in order to support the children accordingly. This study aims at reviewing the teacher beliefs and practices of multi-culture in early childhood classrooms. The review of the teacher beliefs will be based on the questionnaire about multiculturalism. The review of the teacher practices will be based on the one week lesson plan analysis. The findings described the exploration of the teachers beliefs and practices on multiculturalism in early childhood. As the curriculum still currently using the tourist approach, the teacher beliefs and practices in multicultural education are around the objectified culture. However, apart from the findings, this study provides the benefits in another fold: how the process of the investigation raised the teachers' awareness to introduce multiculturalism for young children. All in all, the study hold promise for utilization in future research on teachers beliefs and practices in multicultural education in early childhood education.
\end{abstract}

Keywords-multi-culture; multicultural education; early childhood education

\section{INTRODUCTION}

At first glance, it may seem that only in countries whose population is made up of many different nationalities that the issue of multiculturalism seems urgent. Hence in countries with relatively single nationality with predominantly mono-cultural or bicultural societies, there is no need to study multi-culture. This myth is pervasive in such societies, including in Indonesia. In Indonesia, the majority of the population (about 95\%) are natives (pribumi). However, there are over 300 ethnic groups in Indonesia who live side by side and in some cases form blurred inter-ethnic boundaries. Therefore, the issue of multiculturalism and its place in education is also a great importance in Indonesia.

The national motto stated "Bhinneka Tunggal Ika" means "Unity in Diversity" and it is written on the symbol of the Indonesian state, Garuda Pancasila. Accommodating this slogan, accepting all different ethnics that live in Indonesia, the national curriculum has included the needs to know different ethnical differences in terms of languages, ethnic clothes, songs, and traditions. It is expected to be able to promote respect and tolerance for the differences ethnics in Indonesia and it has been applied to all education levels, starting from the early childhood of education. Since for multicultural education to be effective, it must be taught in the early years of education and reinforced in the later stages [1]. [2] Stress the importance of the multicultural education in the early years. In linear with this view, the Indonesian government emphasized that all children deserved to have education without seeing any difference [3].

This kind of curriculum is effective for an introduction to multicultural education and it is relatively easier to adopt. This approach is chosen since it is believed that it could teach all young people how to respect ethnic and cultural differences and to accept them as part of the cultural richness of life in our modern world, and not as a threat. However, it has met considerable critique as the "tourist approach" since it allows children a brief glimpse into the true nature and traditions of a culture for a limited period and often highly generalized and not representative to such cultures. It is also considered as the most serious pitfall of multicultural education [4] since the culture become objectified, and multicultural activities become "visits" that are separate from the ongoing daily curriculum.

\section{A. Culture and Multiculturalism in a Digital World}

Culture can be seen as a set of fundamental ideas, experiences, and practices of a group, which transmits them through learning. Culture may refer to norms, attitudes, and beliefs, which are used to solve human problems. In addition, we can say that culture is a system of expressive practices and mutual meanings connected to our behaviors. [5].The previous definition is strongly connected to education because in a longterm thinking child are the ones who are to solve problems in the future. There are certain attitudes, norms, and values which exist in schools and which are transmitted through learning. Even though critical thinking is emphasized in schools the culture affects the learning processes.

What is typical for the culture does not necessarily mean it is frequent. Something infrequent can be typical for the culture if it does not exist in any other culture [6]. [7] separates four levels of culture. On the fourth level, we can see behaviors and skills. The third level includes knowledge, beliefs, and values. The second level is not so directly observable by including 
intellectual creativity for coping with level one. The first level consists of physical, historical, geographical, social, political and emotional conditions. This definition is quite wide and gathers together many aspects of life.

In the past two decades, digital technologies have transformed the cultural scene profoundly. New forms of creation, production, distribution, access, and participation have revolutionized entire industries, such as book publishing, music, and film. Then this fact could offer both opportunity and threat to multiculturalism. It would be an opportunity because it is building the bridges between cultures beyond time and space. The possibility to interact with other cultures are growing rapidly. It would shift the function of introducing other culture from the classrooms to digital media. It would be a threat if the young generations are not aware of the needs for cross-cultural understanding.

\section{B. Teachers and Multicultural Education}

One of the other challenges in multicultural education is making sure that the teachers could provide a fair education for students with the purpose of achieving social justice [8]. Multicultural education demands activity from the teachers. It is important to realize one's own cultural background and attitudes and reflect on them critically when facing differences at work [9]. [10] Underlines that in addition to being conscious of differences, teachers should learn to accept them. Teachers, like any other human beings, may have unconscious prejudices. Also, pupils should be given guidance on how to analyze critically one's own culture. When both the teachers and the pupils are aware of their own cultural backgrounds, there is a place for real communication and interaction without trying to change people's values but to become conscious of them [11].

Teachers must also have adequate skills to enable them to integrate the students' different cultures into classroom experiences. In this regard, Sue, Arredondo, and McDavis, (1992) argue that multicultural competence requires the development of three levels of understanding: awareness, $\mathrm{F}$ knowledge, and skills. However, these competencies are hard to acquire [12].

Teachers' perceptions and their trends regarding culturally diverse students in the classroom are an important element in educating, motivating, and making a difference in education among students irrespective of their age, gender, ethnicity, language, and religion. These perceptions and attitudes influence teachers' expectations and treatment of these learners [13].

The main purpose of this research is to investigate the teachers' beliefs about multicultural education and also the practice in early childhood education classrooms. This research is significant because it illustrates teachers' perceptions of multicultural education and how urgent it is to do something bigger to raise the teacher awareness of multicultural education in Indonesia.

\section{METHOD}

\section{A. Participants}

There were 20 kindergarten teachers contacted for this study. All of them are female teachers in Surabaya, Indonesia. Surabaya is the second biggest city in Indonesia. As the capital of East Java province, Surabaya is regarded as a melting pot, one place for such heterogonous society. Eight participants finished all the online survey, while others were not completing the survey. The findings for the teacher's beliefs were based on these eight completed survey. Seven teachers are in the age range of 21-30 years old and 1 teacher is in the age range of 31-40 years old. All teachers have been teaching less than 5 years in early childhood education. They all hold the bachelor degree in Education, and 3 of them hold the bachelor degree in Early Childhood Education. Most of them came from other city than Surabaya - but still within the East Java province, but all of them are working and living in Surabaya. From eight participants, there were three teachers agreed on going for further steps, the analysis of one-week-lesson plans. All of them are female, 21-30 years old, and hold a bachelor degree.

\section{B. Research Design}

This article reported an ethnographic study. Ethnography is a qualitative design in which the researcher describes and interprets the shared and learned patterns of values, behavior, beliefs, and language of a culture-sharing group.

There is two focus in this article. The first one is exploring the teacher beliefs of multiculturalism in the classroom. The data collected for this focus is done through the online questionnaire. The second one is exploring the teacher practices. The data collected for this focus is gathered from the lesson plan for the whole week (no specific theme set).

\section{Instruments}

The instruments for this article were questionnaire made via google forms, therefore they are online surveys consists of three different sections [14]. The first one if the consent and the personal data as described in the participants description.

The second one is the 22 statements with 5-Likert scale. The 22 statements are categorized as described in table 1.

\begin{tabular}{|l|l|l|}
\hline No & Statement description & Amount \\
\hline 1 & Perception of different cultures & 5 \\
\hline 2 & Perception to general attributes to cultures & 5 \\
\hline 3 & Perception to multicultural education & 3 \\
\hline 4 & Related to different values & 3 \\
\hline 5 & Related to different sexes and gender & 2 \\
\hline 6 & Related to different needs in education & 2 \\
\hline 7 & Related to different religions & 1 \\
\hline 8 & Related to different economic background & 1 \\
\hline & Total numbers & 22 \\
\hline
\end{tabular}

Table 1 . The category of the statements

The third one is 4 questions that required longer answer as it provides the opportunity for the participants to elaborate on their choices and reflection. The first two questions are similar, but the first one is asked upon before filling the scale for the statements, and the second one is after. The question is related to the teacher's understanding towards multi-culture. 
The third question leads the participants to reflect upon their understanding of multi-culture before and after reading the statements in the questionnaire. The fourth question invites the participants to think about what would they do after filling in the questionnaire.

\section{Instrument Reliability}

The questionnaire coding key created for this study was submitted to the expert opinion. New encodings were created and agreed and disagreed with coding were determined. In this procedure, Miles and Huberman procedure were utilized [15]. The result from the procedure is that $92 \%$ reliability categorized as reliable (>70\%).

\section{E. Data Analysis}

For the essay part in the section of Teachers' beliefs, all the answers of the teachers were collected and then coded by keywords.

For the section of Teachers' practices, there was the threephase procedure for the analysis of the lesson plans. First of all, the activities of the lesson plans were collected and listed. Then both sides, the researchers and the teachers, were separately coding whether each activity could be used as the delivery for multiculturalism. The last phase was the written discussion between the teachers and the researchers.

Descriptive and thematic analyses were employed in the present study. The thematic analysis which incorporated an inductive approach was used in the present study to identify recurring patterns in the data. The inductive approach was used in the thematic analysis, as it allowed themes to emerge from the data.

\section{RESUlt}

\section{A. Teachers Beliefs}

Seven out of eight teachers explained multicultural education from the "tourist approach". The keywords showed up for the pre-questionnaire question asking the teacher "perception of what multi-culture is" are as follows: tradition, language, clothes, songs, and religions. One teacher elaborates more by adding gender and different ability in education.

The questionnaire was using the mixed order feature from the google-forms, so each participant got the questionnaire in different orders. The table 2 shows the result from the questionnaire.

\begin{tabular}{|l|c|c|c|c|c|}
\hline Statements & 1 & 2 & 3 & 4 & 5 \\
\hline $\begin{array}{l}\text { Interested in exploring cultures } \\
\text { different from my own }\end{array}$ & & & & 60 & 40 \\
\hline $\begin{array}{l}\text { Have enough experience with } \\
\text { cultures different from my own }\end{array}$ & 20 & 40 & 40 & 20 \\
\hline $\begin{array}{l}\text { I feel comfortable around people } \\
\text { whose cultural background is } \\
\text { different from mine }\end{array}$ & 80 & 20 & & & \\
\hline $\begin{array}{l}\text { It bothers me when I hear people } \\
\text { talking in a language I cannot } \\
\text { understand }\end{array}$ & & & 20 & 60 & 20 \\
\hline $\begin{array}{l}\text { Important for people to examine } \\
\text { possible personal prejudices }\end{array}$ & & & & \\
\hline
\end{tabular}

\begin{tabular}{|c|c|c|c|c|c|}
\hline $\begin{array}{l}\text { Women have equal opportunities to } \\
\text { be as successful as men }\end{array}$ & & & & 60 & 40 \\
\hline $\begin{array}{l}\text { It is important to be sensitive to } \\
\text { issues related to sexual orientation }\end{array}$ & & & & 60 & 40 \\
\hline $\begin{array}{l}\text { Additional school resources are } \\
\text { appropriately expended in meeting } \\
\text { the needs of students with special } \\
\text { needs }\end{array}$ & & 40 & 20 & 20 & 20 \\
\hline $\begin{array}{l}\text { With appropriate resources, people } \\
\text { with intellectual disabilities can be } \\
\text { as successful as people without } \\
\text { disabilities }\end{array}$ & & & & & $\begin{array}{c}10 \\
0\end{array}$ \\
\hline $\begin{array}{l}\text { Believe that some cultures and } \\
\text { ethnic groups are better than others }\end{array}$ & 20 & & 60 & 20 & \\
\hline $\begin{array}{l}\text { Members of all racial and ethnic } \\
\text { groups make valuable contributions } \\
\text { to society }\end{array}$ & & & & 40 & 60 \\
\hline $\begin{array}{l}\text { Multicultural education should be } \\
\text { an important part of a school } \\
\text { curriculum }\end{array}$ & & & 20 & 40 & 40 \\
\hline $\begin{array}{l}\text { I consider particular attitudes or } \\
\text { behaviors of children be a direct } \\
\text { consequence of cultural or ethnic } \\
\text { differences }\end{array}$ & & & 20 & 80 & \\
\hline $\begin{array}{l}\text { A teacher's role should be limited } \\
\text { to promoting the only mainstream } \\
\text { culture }\end{array}$ & 20 & 20 & 20 & 40 & \\
\hline $\begin{array}{l}\text { Members of all racial and ethnic } \\
\text { groups have equal opportunities to } \\
\text { be successful }\end{array}$ & & & & 40 & 60 \\
\hline $\begin{array}{l}\text { It is acceptable to tell racial or } \\
\text { ethnic jokes }\end{array}$ & 100 & & & & \\
\hline $\begin{array}{l}\text { Given equal intelligence and } \\
\text { ability, every individual has equal } \\
\text { access to success }\end{array}$ & & 40 & & & 60 \\
\hline $\begin{array}{l}\text { Teaching about various world } \\
\text { religions should be a part of the } \\
\text { public school curriculum }\end{array}$ & & & & 60 & 40 \\
\hline $\begin{array}{l}\text { Students from economically } \\
\text { disadvantaged families should be } \\
\text { expected to achieve as well as } \\
\text { those from more advantaged } \\
\text { families }\end{array}$ & & & & 20 & 80 \\
\hline $\begin{array}{l}\text { I am comfortable teaching in } \\
\text { culturally diverse classrooms with } \\
\text { students who share different value } \\
\text { systems }\end{array}$ & & 40 & & 20 & 40 \\
\hline $\begin{array}{l}\text { Values and attitudes learned in } \\
\text { minority cultures keep children } \\
\text { from making progress in school }\end{array}$ & & 60 & 40 & & \\
\hline $\begin{array}{l}\text { I feel I can understand the point of } \\
\text { view of a child who comes from a } \\
\text { culture different than my culture }\end{array}$ & & & 40 & 40 & 20 \\
\hline
\end{tabular}

1) $1=$ fully disagree, $2=$ =disagree, $3=$ neutral, $4=$ agree, $5=$ fully agree

2) The numbers are showing the percentage

Table 2. Questionnaire Result 
The results from the second section, asking about the teacher's perception of multicultural education are elaborated extensively. The five keywords (tradition, language, clothes, songs, and religions) are still there, but all teachers added them with gender, different ability in education, and economic status, which are basically the items in the questionnaire. The teachers, in the next essay item, also admitted that their answers differently because they then realized that multiculture is much more than the festive items.

The results from the third section asking the teachers' plan if they do find something new out of this study. The answers were coded and categorized into two aspects, planning for selfdevelopment and planning for practice, as described in table 3.

\begin{tabular}{|l|l|}
\hline Category & Description \\
\hline $\begin{array}{l}\text { Self- } \\
\text { development }\end{array}$ & Reading about multiculturalism \\
\hline & $\begin{array}{l}\text { Getting in touch with friends from different } \\
\text { places in Indonesia }\end{array}$ \\
\hline & $\begin{array}{l}\text { Reading about the different culture in Indonesia } \\
(2)\end{array}$ \\
\hline Practice & $\begin{array}{l}\text { Grouping the children and re-arrange the } \\
\text { groups occasionally }\end{array}$ \\
\hline & Teaching how to accept differences (3) \\
\hline
\end{tabular}

\section{B. Teacher Practices}

There were one-week lesson plans from three teachers. The focus is about comparing the teachers and the researchers rate the activities. The rating is based on the question whether the activity could be a way to deliver the multiculturalism in the classroom.

The number of activities within one week is 24,27 , and 29 activities in each lesson plan. These activities are including the school common procedure like praying and washing hands before and after school. For the coding, the same type of activities was left out.

From those number of activities within one week, the teacher rated that there was 2 or less activity that can deliver the multicultural education. All teachers argued that the theme for the week does not fit the theme of multiculturalism or related to culture.

Based on the researchers rating, there were at least five to seven activities could be good activities to deliver the message for recognizing and accepting differences.

\section{CONCLUSION AND Discussion}

For multicultural education to be effective, it must be taught in the early years of education and reinforced in the later stages [1]. The early years are a time when young children are internalizing knowledge about the moral values and ethical standards of their society. In the early years, the child's family plays the leading role in socializing the child with the manners, views, beliefs, and ideas held within their culture [16]. These statements highlight the fact that the tenets of multiculturalism can be incorporated into early childhood education. Nevertheless, there has been little to any investigation of multicultural education in the Indonesian context. The present research explores the beliefs and practices of preschool teachers in Surabaya, Indonesia about multiculturalism.

The exploration of the teacher beliefs shows that most teachers had a limited understanding of multiculturalism, however, they showed a considerable positive tendency towards it. The exploration of the teacher practices shows two important notes. One is that teachers should not only adopt a 'tourist approach' to multiculturalism which stereotypes other cultures and turns the multicultural curriculum into a 'tourist curriculum' [4] 'Tourist curriculum' which teaches about cultures through celebrations and artifacts of culture, such as food and traditional clothing, is both patronizing and trivializing and does not provide a real understanding of other cultures. Teachers need to understand their own beliefs about culture and diversity in order to implement multicultural education programs effectively with young children. They may start with the accepting diversity among the children, the simple ones like different heights and languages. The second one is the one that the teacher was not aware of the possibility of teaching about differences and tolerances explicitly as it is the very core of multi-culture in the classroom.

The promising results show that this research is worth going further, with more participants, as one limitation of the study is that the low number. The low return rate of the online questionnaire showed that having the online survey was not the best way to conduct the study within the early childhood teachers. One interesting finding from the exploratory analysis is that the study is proven effectively that it helps in raising the teacher awareness in the multicultural classroom. As the world of the future is and will be increasingly become digital and therefore, multicultural. The dynamic changes in how children learn and live challenged the teachers to go deeper than the "tourist" curriculum for the multicultural education.

\section{REFERENCES}

[1] G. Eason, B. Noble, and I.N. Sneddon, "On certain integrals of Lipschitz-Hankel type involving products of Bessel functions," Phil. Trans. Roy. Soc. London, vol. A247, pp. 529-551, April 1955. (references)

[2] W. Robles de Melendez and V. Ostertag, "Critical multiculturalism: rethinking multicultural and antiracist education," ed: Boston, MA: Delmar Publishers, 1997.

[3] I. Siraj-Blatchford and P. Clarke, Supporting identity, diversity and language in the early years: McGraw-Hill Education (UK), 2000.

[4] A. Wartini, "Multicultural-based Education on Indonesian Character in Early Childhood Education," Ta'dib: Journal of Islamic Education (Jurnal Pendidikan Islam), vol. 21, pp. 201-214, 2016.

[5] L. Derman-Sparks and J. O. Edwards, Anti-bias education for young children and ourselves: National Association for the Education of Young Children Washington, DC, 2010.

[6] G.-M. Chen, Foundations of intercultural communication: University Press of America, 1998.

[7] L. H. Ekstrand, Multicultural education: Department of Educational and Psychological Research, 1994.

[8] S. Mushi*, "Multicultural competencies in teaching: a typology of classroom activities," Intercultural Education, vol. 15, pp. 179-194, 2004.

[9] S. Lappalainen, "Liberal multiculturalism and national pedagogy in a Finnish preschool context: inclusion or nation-making?," Pedagogy, Culture \& Society, vol. 14, pp. 99-112, 2006. 
[10] K. Jokikokko*, "Interculturally trained Finnish teachers' conceptions of diversity and intercultural competence," Intercultural Education, vol. 16, pp. 69-83, 2005

[11] M.-T. Talib, Diversity: A challenge for educators: Finnish Educational Research Association, 2006.

[12] M. Byram, B. Gribkova, and H. Starkey, "Developing the intercultural dimension in language teaching," A practical introduction for teachers. Strasbourg: Council of Europe, 2002.

[13] J. Garcia and S. L. Pugh, "Multicultural education in teacher preparation programs: A political or an educational concept?," The Phi Delta Kappan, vol. 74, pp. 214-219, 1992.
[14] J. Le Roux, "Effective Teacher Training for Multicultural Teaching," MCT, vol. 19, pp. 18-22, 2001.

[15] D. W. Sue, P. Arredondo, and R. J. McDavis, "Multicultural counseling competencies and standards: A call to the profession," Journal of Counseling \& Development, vol. 70, pp. 477-486, 1992.

[16] M. B. Miles and A. M. Huberman, "Qualitative data analysis: A sourcebook of new methods," in Qualitative data analysis: a sourcebook of new methods, ed: Sage publications, 1984.

[17] J. Garbarino, Children and Families in the Social Environment: Modern Applications of Social Work: Routledge, 2017. 